\title{
Molecular fingerprinting defines a strain of Salmonella anatum responsible for an international outbreak associated with formula-dried milk
}

\author{
E.J. Threlfall*, L.R. Ward*, B. Rowe*, D. Roberts**, P.G. Wall ${ }^{+}$
}

\begin{abstract}
Abstrak
Pada Januari 1997, Laboratorium Patogen Enterik (LEP) dari Laboratorium Pelayanan Kesehatan Masyarakat Inggris dan Wales, mencatat peningkatan jumlah isolat Salmonella anatum yang berasal dari bayi - bayi berumur 1-11 bulan yang ditemukan pada bulan November dan Desember 1996. Pusat Infeksi dan Kesehatan Lingkungan Scottish juga melaporkan 4 kasus S. anatum pada bayi-bayi pada periode Oktober 1996-January 1997. Pada akhir Januari 1997, dari 52 isolat S. anatum yang masuk ke LEP selama 13 bulan dari 1 Januari 1996- 31 Januari 1997, 18 isolat berasal dari bayi dan 2 dari keluarga kasus. Analisis molekuler menggunakan typing profil plasmid dan pulsed-field gel electrophoresis (PFGE) menunjukkan adanya galur epidemik $\mathrm{S}$. anatum yang berhubungan dengan konsumsi susu kering bayi merek tertentu, dan produk tersebut ditarik dari pasar di Inggris. Galur ini juga diidentifikasi pada 2 dari 3 isolat S. anatum yang berasal dari bayi-bayi di Perancis. Peranan DNA fingerprinting pada kejadian luar biasa S. anatum tahun 1996-1997 akan didiskusikan lebih lanjut.
\end{abstract}

\begin{abstract}
In January 1997 the Laboratory of Enteric Pathogens (LEP) of the Public Health laboratory Service of England and Wales recognised that the number of isolates of Salmonella anatum from infants aged 1 to 11 months had risen in November and December 1996. The Scottish Centre for Infection and Environmental Health also reported four cases of S.anatum in infants in the period October 1996January 1997. By the end of January 1997, of 52 isolates of S. anatum received in LEP in the 13-month period January 1 1996- January 31 1997, 18 were from infants and two were from relatives of cases. Molecular analyses based on plasmid profile typing and pulsed-field gel electrophoresis (PFGE) defined an epidemic strain of S. anatum associated with the consumption of particular brand of infant dried milk and the product was withdrawn from sale in the UK. The epidemic strain was subsequently identified in two of three isolates of S. anatum from infants in France, which prompted a withdrawal of the product in that country and two weeks later the epidemic strain was isolated from the product. The role of DNA fingerprinting in the 1996-97 international outbreak of $\mathrm{S}$. anatum is discussed.
\end{abstract}

\section{INTRODUCTION}

In January 1997 the Laboratory of Enteric Pathogens (LEP) of the Public Health Laboratory Service (PHLS) of England and Wales recognised that the number of isolates of Salmonella indiana from infants aged from 1 to 11 months had risen in November and December 1996. The Scottish Centre for Infection and Environmental Health also reported four cases of $S$. anatum in the period October 1996 - January 19971. By the end of January 1997, of 52 isolates of $S$. anatum received in LEP in the 13-month period January 1, 1996 to January 31, 1997, 18 were from

\footnotetext{
* Laboratory of Enteric Pathogens

**Food Hygiene Laboratory, Central Public Health Laboratory London NW9 5HT, U.K.

${ }^{+}$Communicable Disease Surveillance Centre, Public Health Laboratory Service, London NW9 SEQ, U.K.
}

infants and 2 were from relatives of cases. Because of the highly-significant association of $S$. anatum with a particularly vulnerable population (infants), an investigation into the putative outbreak was jointly mounted by the LEP, the Food Hygiene Laboratory and by the Communicable Disease Surveillance Centre (CDSC) of the PHLS. collaborating laboratories in the European Union- funded Salm-Net project were also notified electronically of the putative outbreak.

\section{CASE-CONTROL STUDY}

In a case-control study carried out by CDSC in the week commencing 20-24 January 1997, 10/12 infants infected with $S$. anatum were found to have consumed a particular brand of formula-dried milk (Milumil). In contrast, of 40 infants not infected with $S$. anatum, only 3 had been fed Milumil. A preliminary report of this study has been published elsewhere ${ }^{2}$. 


\section{MICROBIOLOGICAL INVESTIGATIONS}

Molecular analyses based on plasmid-profile typing and pulsed-field gel electrophoresis (PFGE) demonstrated that the putative outbreak strain was defined by carriage of a plasmid of 50 megadaltons (PPT E) and by a particular pulsed-field profile (PFP 5). None of over 50 isolates of $S$. anatum isolated in the UK from 1994 to 1997 and not associated with the putative outbreak either carried the $50 \mathrm{MDa}$ plasmid or belonged to PFP type 5.

As a result of these epidemiological and microbiological results the product was withdrawn from the UK market on January 24, 1997. However it should be noted that at this stage the possibility that the product had been contaminated with $S$. anatum had not been microbiologically confirmed.

\section{INTERNATIONAL INVESTIGATIONS}

As a result of notification of the outbreak through the Salm-Net network, 4 isolates of $S$. anatum which had been made from infants in France in the last quarter of 1996 were referred to the LEP. Of these 3 isolates, all from infants who had consumed Milumil, had the molecular characteristics of the UK outbreak strain. The remaining isolate, from an infant who had not consumed Milumil, had a different plasmid- and pulsed-field profile from the outbreak strain.

As a result of the international investigation, the product was withdrawn from sale in France on 8 February 1997.

\section{ISOLATION FROM FOOD}

On February 20, 1997 a strain of Salmonella was isolated from an unopened packet of Milumil purchased in the UK. The organism was identified as $S$. anatum and molecular analysis subsequently demonstrated that the strain was indistinguishable from the strain which had caused infections in infants in the UK and France.

\section{OVERALL CONCLUSIONS}

An outbreak of $S$. anatum in infants in the UK and France in late 1996/early 1997 associated with a particular formula-dried milk product was caused by a strain with a distinctive plasmid- and pulsed-field profile. The study demonstrates the value of laboratory-based surveillance involving detailed phenotypic and genotypic characterisation of putative outbreak strains coupled with food microbiology and targeted epidemiological investigations.

\section{REFERENCES}

1. Anon. Salmonella anatum infection in infants linked to dried milk. CDR Wkly Rep 1997a; 5: 35-6.

2. Anon Public Health Laboratory Service (PHLS), Laboratory of Enteric Pathogens et al. Preliminary report of an international outbreak of Salmonella anatum infection linked to infant formula milk. Eurosurveillance 1997b; 2: 22-4. 